\title{
Massarina ingoldiana, a new ascomycete from freshwater habitats
}

\author{
C. A. Shearer ${ }^{1}$ \\ Department of Plant Biology, University of Illinois, \\ Rm. 265 Morrill Hall, 505 South Goodwin St., \\ Urbana, Illinois \\ K. D. Hyde \\ Department of Ecology and Biodiversity, University of \\ Hong Kong, Pokfulham Rd., Hong Kong
}

\begin{abstract}
A Species of Massarina (Pleosporales) was found on woody debris in aquatic habitats in several countries. This new species is characterized by its transversely septate ascospores that are surrounded by a large, gelatinous sheath. The pattern of ascospore appendage enlargement is very similar to that of another freshwater ascomycete, Pleospora scirpicola.

Key Words: Ascomycetes, aquatic, Pleosporales, systematics
\end{abstract}

\section{INTRODUCTION}

An ascomycete with a very distinctive ascospore sheath was encountered in a variety of freshwater habitats in Australia, Brunei Darussalam, Malaysia, and North America. The morphological features of this fungus support its placement in the genus Massarina Sacc. (Lophiostomataceae, Pleosporales, Loculoascomycetes). The unusual ascospore sheath distinguishes it from other species of Massarina and it is therefore described as a new species.

\section{MATERIALS AND METHODS}

Submerged woody and herbaceous debris was collected from aquatic habitats and returned to the laboratory for incubation in moist chambers (Shearer, 1993). After initial examination, samples were incubated at room temperature and examined periodically over 6-12 mo. Abbreviations for collectors names are JLC for J. L. Crane, KDH for K.D. Hyde, and CAS for C.A. Shearer.

To observe details of ascomal anatomy and centrum structure, ascomata were fixed in $4 \%$ glutaraldehyde, embedded in ultra-low viscosity resin (Huhn-

Accepted for publication August 12, 1996.

${ }^{1}$ Email: carolshe@uiuc.edu dorf, 1991) and sectioned at $6 \mu \mathrm{m}$. Thin sections were mounted on gelatin coated microscope slides and permanently preserved using a 1:1 mixture of Permount and Xylene. Squash mounts of ascomata in water were made to observe the ascomal wall in face view, asci, paraphyses and ascospores. India ink was added to water mounts to observe the ascospore sheath. Measurements of ascomata were made from thin sections or whole mounts in water. All other measurements were made in lactic acid with azure A.

Single spore isolates were obtained according to the procedures of Shearer (1993). To confirm identities of cultures, isolates were induced to fruit by growing them on alfalfa stems submerged in water and then incubating the colonized alfalfa stems in moist chambers. To test for the presence of an Ingoldian hyphomycete anamorphic state, thin strips of colonized cornmeal agar (Difco) were submerged in sterile, distilled water and incubated at $17 \mathrm{C}$.

\section{TAXONOMY}

Massarina ingoldiana Shearer et Hyde, sp. nov.

FIGS. 1-13

Ascomata 180-310 $\mu \mathrm{m}$ alta, 185-500 $\mu \mathrm{m}$ diam, subglobosa, immersa vel superficialia, nigra, ostiolata, sub clypeo immersa, solitaria vel gregaria. Rostrum cylindricum, centrale, periphysatum, 65-113 × 73-122 $\mu \mathrm{m}$. Asci fissitunicati, octospori, anguste oblongi vel cylindrici, stipitati, cavernula apicali praediti vel non, 98-250 × 20-44 $\mu \mathrm{m}$. Pseudoparaphyses septatae, anastomosantes, 1.5-3 $\mu \mathrm{m}$ diam. Ascosporae 3-4 seriatae, 1-septatae, tum 3-subinde 5-septatae, fusiformes, hyalinae, serius palide brunneae, 38-70 $\times 7-16 \mu \mathrm{m}$, involucro gelatinoso circumfusae in aqua dilatato.

HOLOTYPUS. ILLS.

Etymology. Named in honor of Professor C. T. Ingold for his pioneering work with freshwater ascomycetes.

Colonies on Emerson's yeast extract soluble starch agar immersed with a dense flattened mat of aerial hyphae; immersed hyphae brown-black, aerial hyphae dark golden brown; hyphae causing a brown pigmentation of the surrounding agar. Ascomata 180-310 $\mu \mathrm{m}$ high, 185-500 $\mu \mathrm{m}$ diam, solitary to clustered, immersed, becoming superficial by sloughing off of host, subglobose to flattened globose, ostiolate, papillate, \pm clypeate, black (FIGS. 1,4). Peridium 
20-48 $\mu \mathrm{m}$ wide, inner layer of hyaline, elongate thin-walled cells, 20-30 $\times$ 4-7 $\mu \mathrm{m}$ at sides, 12-16 $\times 4-6 \mu \mathrm{m}$ at base, outer layer of very small, thin-walled, isodiametric, often compressed cells, outer cells interspersed among host cells, outermost cells and cells of clypeus occluded with brown, amorphous material (Figs. 1, 2). Beak central, cylindrical, periphysate, $65-113 \times 73-122 \mu \mathrm{m}$, wall thicker at base, outer cells at base darkened and occluded with brown amorphous material, forming a clypeus-like structure (FIGs. 1, 2). Pseudoparaphyses septate, 1.5-3.0 $\mu \mathrm{m}$ wide, hyphae-like, hyaline, anastomosing, embedded in a gelatinous matrix (FIgs. 5, 6). Asci fissitunicate, oblong to cylindrical, broadly rounded at apex, tapering to stipe at base, 98-250 $\times 20-44$ $\mu \mathrm{m}$, (type specimen $-146-220 x=188 \times 25-36, x=28.3$ $\mu \mathrm{m}, n=20$ ) thick-walled: wall at side $2-6 \mu \mathrm{m}$ thick, wall at apex 8-22 $\mu \mathrm{m}$ thick, with or without a very short cylindrical apical chamber; stipe short, 14-22 × 4-6 $\mu \mathrm{m}$, often strongly curved (FIGs. 5-7). Ascospores 3-4 seriate, 1-septate, becoming 3-5-septate late in development, fusiform, slightly constricted at mid-septum, hyaline, becoming pale brown with age, 38-70 $\times 7-16 \mu \mathrm{m}$ (type specimen $-46-62 x=53.7 \times$ $7-12 x=9.83 \mu \mathrm{m}, n=30$ ), filled with small lipid droplets to give a foamy appearance (FIG. 8), often guttulate (FIG. 9), surrounded by a fusiform gelatinous sheath (FIGS. 3, 8) which expands to form a long, amorphous, sticky enveloping sheath (FIGS. 10-13).

HOLOTYPE. UNITED STATES. WISCONSIN: Adams County, Lemonweir River, $43^{\circ} 46^{\prime} 16^{\prime \prime} \mathrm{N}, 89^{\circ} 53^{\prime} 10^{\prime \prime} \mathrm{W}$, on submerged, decorticated woody debris, 31 July 1992, CAS Eे JLC A-39-1 (ILLS 52289); culture from the holotype, ATCC 200398 (ILLS 52290).

Additional material examined. AUSTRALIA. NORTH QUEENSLAND: Kuranda, Top of the range, on submerged wood, Dec. 1991, KDH [HKU(M) 1552]; Babinda, Boulders National Park, on submerged twig, 30 Dec. 1991, $\mathrm{KDH}$ [HKU(M) 879]. BRUNEI DARUSSALAM. Temburong, Sungai Belalong, Sungai Esu, on submerged wood in rainforest stream, 28 Feb 1994, KDH E W. S. Wong SE14, [HKU(M) 1938]; July 1993, KDH [HKU(M) B166]. MALAYSIA. Sungai Lipur Lentang, Oct. 1991, KDH [HKU(M) 1573]. UNITED STATES. FLORIDA: Big Cypress Nature Preserve, Monroe Station, $25^{\circ} 48^{\prime} 16.3^{\prime \prime} \mathrm{N}$, $81^{\circ} 6^{\prime} 2.7^{\prime \prime} \mathrm{W}$, on bark of submerged corticated wood, 29 Dec. 1994, CAS E于 JLC A-39-4 (ILLS 52296). ILLINOIS: Alexander County, Horeshoe Lake, $37^{\circ} 6^{\prime} 59^{\prime \prime} \mathrm{N}, 89^{\circ} 19^{\prime} 25^{\prime \prime} \mathrm{W}$, on partially decorticated submerged woody debris, 11 Mar. 1994, CAS E JLC A-39-3 (ILLS); Johnson County, Elvira Cypress Swamp, Deer Pond, $37^{\circ} 25^{\prime} 43.2^{\prime \prime} \mathrm{N}, 88^{\circ} 56^{\prime} 2.7^{\prime \prime} \mathrm{W}$, on bark of submerged corticated wood, 3 Sept. 1994, CAS E JLC A-39-6 (ILLS). MAINE: York County, Shaker Pond, $43^{\circ} 29^{\prime} 33^{\prime \prime} \mathrm{N}, 70^{\circ} 43^{\prime} 15^{\prime \prime} \mathrm{W}$, on bark of submerged corticated wood, 3 July, 1994, CAS E JLC $A$-39-5 (ILLS 52297). VIRGINIA: Great Dismal Swamp, $36^{\circ} \mathrm{N}, 76^{\circ} 31^{\prime} 42^{\prime \prime} \mathrm{W}$, on submerged herbaceous stem, 17 May 1993, CAS E JLC A-140-1 (ILLS
52295). WISCONSIN: Adams County, Lemonweir River, $43^{\circ} 46^{\prime} 16^{\prime \prime} \mathrm{N}, 89^{\circ} 53^{\prime} 10^{\prime \prime} \mathrm{W}$, on bark of submerged, corticated woody debris, 25 Sept. 1993, CAS $\mathcal{E}$ JLC, A-140-2 (ILLS 52291); on bark of submerged, corticated woody debris, 18 May 1995, CAS E゚ JLC A-39-13 (ILLS); Richland County, Wisconsin River, Lower Wisconsin River State Wildlife Area, $43^{\circ} 12^{\prime} 40^{\prime \prime} \mathrm{N}, 90^{\circ} 20^{\prime} 8.9^{\prime \prime} \mathrm{W}$, on partially decorticated submerged woody debris, 29 Oct. 1993, CAS E JLC A-140-3 (ILLS 52293).

This fungus fits within the generic concept of Massarina in having pseudothecia of pseudoparenchymatous cells, cellular pseudoparaphyses, and one septate hyaline ascospores, tardily becoming $3-5$ septate and darkened, and surrounded by a gelatinous sheath. Munk (1956) noted the presence of small darkened round cells around the ostiole found in the type species of Massarina, M. eburnea (Tul. \& C. Tul.) Sacc. which he referred to as the inter alia. Later Munk (1957) referred to this region as a "clypeusstroma". Whether or not the darkened tissue at the base of the beak of $M$. ingoldiana (FIGs. 1, 2) is homologous to the "clypeus-stroma" of M. eburnea is not clear. Collections that developed under the epidermis of corticated wood were usually found immersed in a common clypeus-like tissue. Massarina ingoldiana differs from other Massarina species in that the ascospores are constricted only at the midseptum rather than at the midseptum and in both hemispheres as well, in the foamy appearance of the ascospores, and in the extremely large ascospore sheath.

Several other Massarina species have been reported from freshwater (Magnes and Hafellner, 1991; Leuchtmann, 1984), including some with aquatic hyphomycete anamorphs (Webster, 1965; Willoughby and Archer, 1973; Webster and Descals, 1979; Scheuer, 1991); five species have been reported from marine habitats (Kohlmeyer and Volkmann-Kohlmeyer, 1991). Barr (1987) questioned the placement of species with aquatic hyphomycete anamorphs in Massarina given that other anamorphs reported for the genus are coelomycetous. Several different isolates of $M$. ingoldiana were tested for the production of aquatic hyphomycete anamorphs, but none was observed and no other anamorphs were produced in culture either. Whether the group of species with aquatic hyphomycete anamorphs represents an evolutionary line distinct from Massarina, whether or not $M$. ingoldiana belongs in such a group, and how closely the marine Massarina species are related to the freshwater and terrestrial species are interesting questions worthy of additional study.

Considerable morphological variation occurred among the different populations of $M$. ingoldiana 
Mycologia
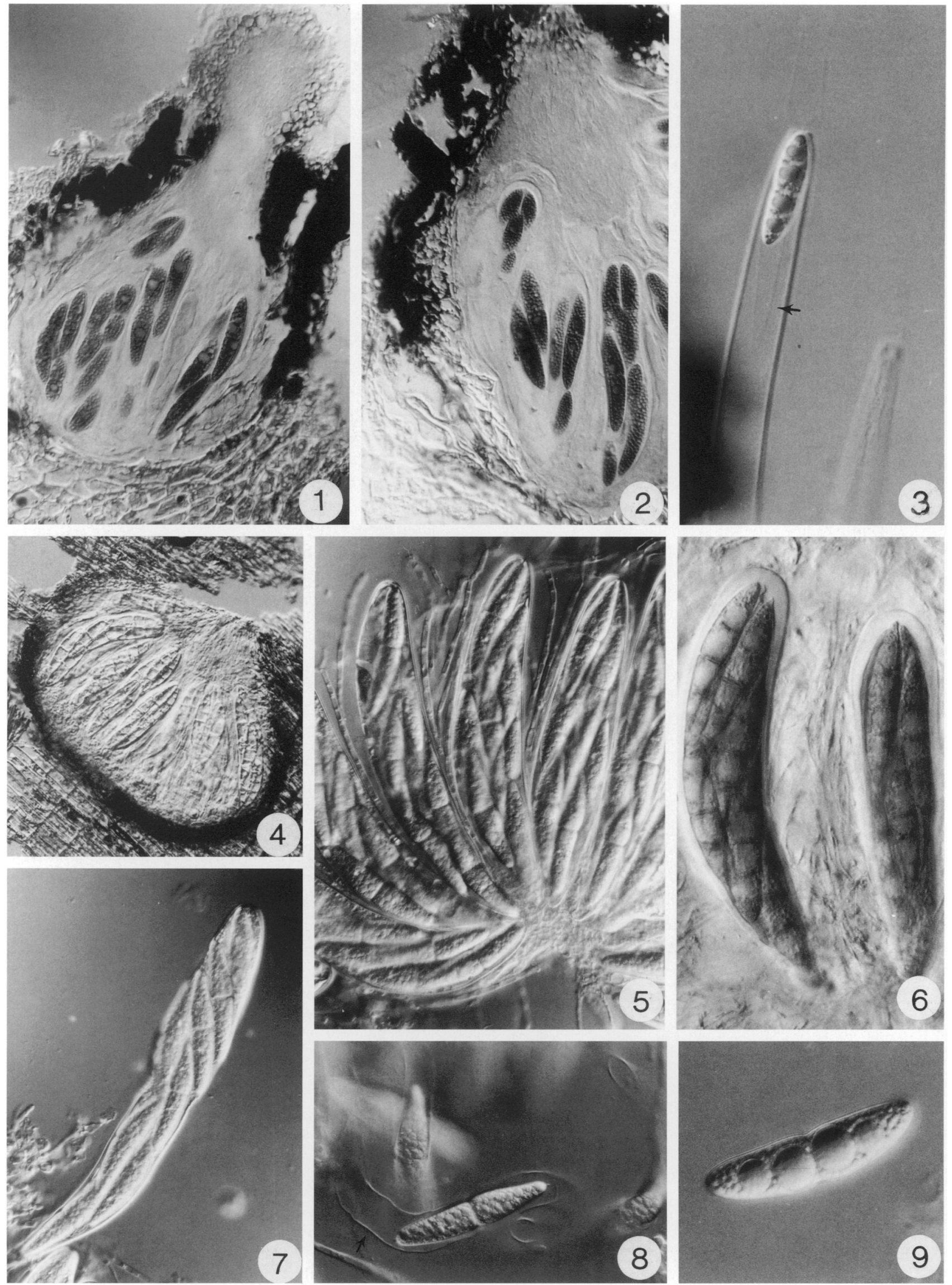

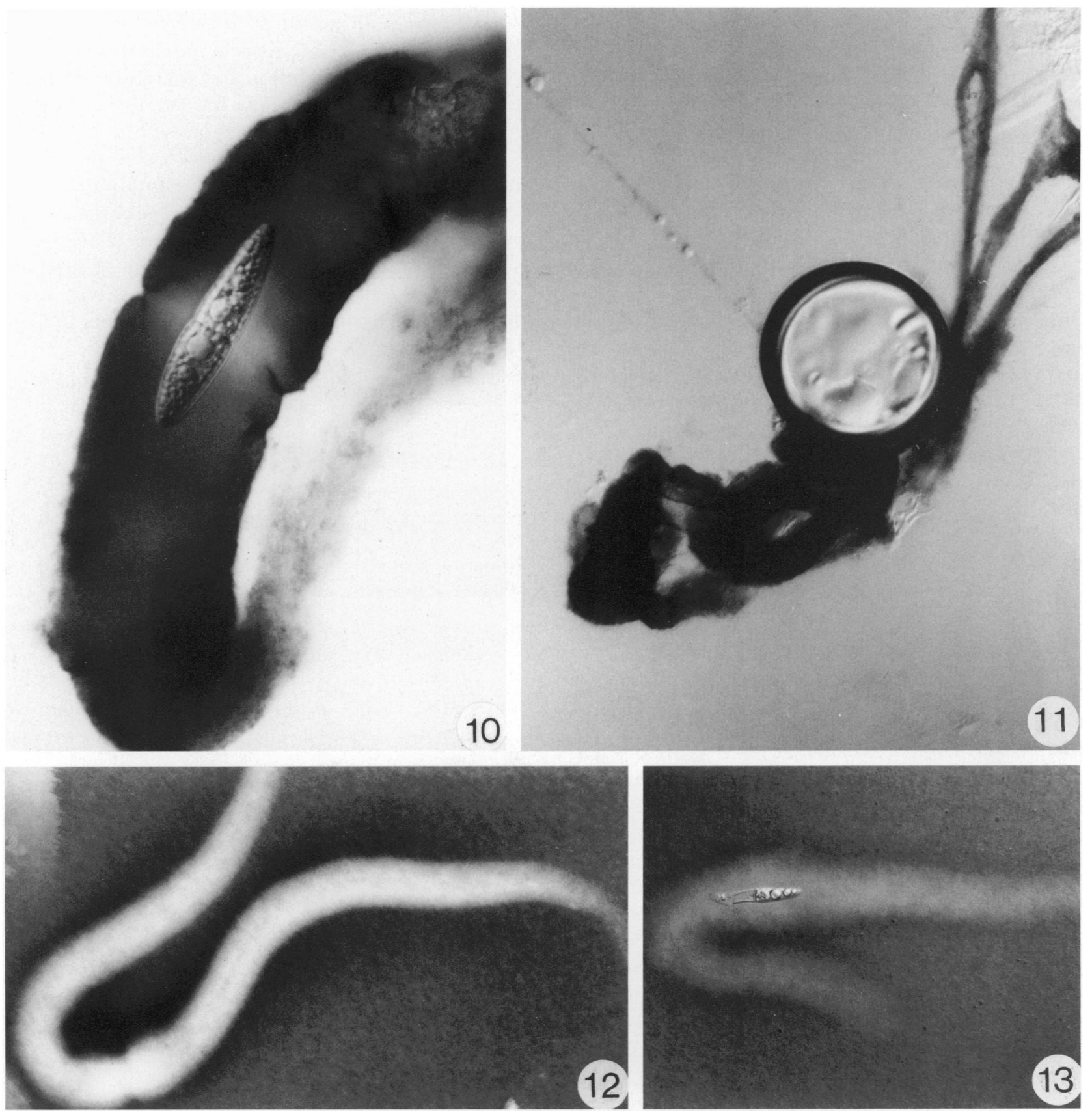

FIGs. 10-13. Massarina ingoldiana. 10-12. From type specimen, ILLS. 10, 11. Material has been mounted in water, stained with India ink, and then rinsed with water. 10. Ascospore surrounded by a gelatinous sheath, $\times 860.11$. Sticky sheaths of several ascospores adhering to an air bubble, $\times 150$. 12. Ascospore with sheath immersed in India ink, $\times 180.13$. From specimen A-140-2. Ascospore with sheath immersed in India ink, $\times 135$.

$\leftarrow$

Figs. 1-9. Massarina ingoldiana. 1, 2. From type specimen, ILLS. 1. Median section through ascoma, $\times 325.2$. Median section through an ascoma showing darkened clypeus-like region around wall of beak, $\times 335$. 3. From specimen $A-140-2$. Ascospore with fusiform sheath (arrow) being discharged from endoascus, $\times$ 440. 4. From specimen HKU(M) 1552 . Partial section through an ascoma, $\times 660$. 5. From specimen $A-140-2$. Asci and paraphyses from fresh material, $\times 304$. 6. From specimen $\mathrm{HKU}(\mathrm{M})$ 1552. Asci showing thick wall, $\times$ 450. 7, 8. From specimen $A-140-2$. 7. Endoascus emerging from ectoascus, $\times$ 315. 8. Ascospore showing foamy appearance of ascospore and unexpanded ascospore sheath (arrow), $\times 390.9$. From specimen $\mathrm{HKU}(\mathrm{M})$. Guttulate ascospore in water; sheath is no longer visible, $\times 720$. 
sampled. The thickness of the ascomal wall and the length of the papilla/beak varied among populations and with substratum. Lengths and widths of ascospores and the degree of secondary septation and pigmentation also varied among populations. In some cases, secondary septa were observed in ascospores within asci, while in most cases, they were observed only in ascospores that had been released from asci.

The most consistent and distinguishing morphological characters are the ascospore sheath and the foamy appearance of the ascospore due to the presence of small lipid droplets. The ascospore sheath is extremely similar to that of Pleospora scirpicola (D. C.) Karst. (Ingold, 1955). Immediately after ascospore discharge, the sheath appears as a well-defined, fusiform covering with definite margins (FIGs. 3, 8). Soon thereafter, the sheath rapidly enlarges to an enormous size without definite margins and appears to be sticky, adhering to debris particles, air bubbles and glass microscope slides (FIGS. 10-13). Unfortunately, the sheath is completely invisible and the lipid droplets are cleared in lactic acid, and therefore, cannot be seen in slides deposited in herbaria or in fresh or dried material mounted directly into lactic acid. The sheath, once hydrated, cannot be seen in water (Fig. 9) unless India ink is added to the slide (FIGS. 10-13). The elongated, sticky sheath probably enables this fungus to attach to substrata in moving water.

Hyde (1995a) provided a description of Massarina eburnea (Tul. \& C. Tul.) Sacc, the type of Massarina. Ascospores in this species have a narrow sheath and are four-celled. In fact, mucilaginous sheaths are a common feature in species of Massarina in marine, freshwater and terrestrial habitats. In the marine species $M$. thalassiae Kohlm. \& Volkm.-Kohlm. and $M$. velataspora $\mathrm{K}$. D. Hyde \& Borse the ascospores are surrounded by regular, wide, spreading sheaths (Hyde and Borse, 1986; Kohlmeyer and VolkmannKohlmeyer, 1987), while in $M$. armatispora K. D. Hyde et al. the sheath is drawn out at the ends (Hyde et al., 1992). In the freshwater species M. bipolaris $\mathrm{K}$. D. Hyde and M. fronsisubmersa K. D. Hyde appendages are drawn out at the ends and contain an inner spine-like structure (Hyde, 1994, 1995b). Many of the terrestrial species of Massarina from palms also have sheaths. In M. palmetta (Cooke) M. E. Barr the ascospores are surrounded by a condensed sheath, 2 $\mu \mathrm{m}$ wide, while in M. palmicola K. D. Hyde \& Aptroot, the sheath is invaginated at the central septum but swells around the ends of the spore (Hyde and Aptroot, 1996). The morphology of the sheath in $M$. ingoldiana, which enlarges to enormous size, is unlike that found in any other Massarina species. Our experience indicates there to be little overlap among the species of Massarina occurring in freshwater, marine or terrestrial habitats, and therefore, we do not consider that $M$. ingoldiana has been described previously.

Massarina ingoldiana appears to be widely distributed geographically and occurs in both lotic and limnetic habitats. It occurs primarily on corticated and decorticated woody debris; only one collection, $A$ 140-1, was found on nonwoody plant debris. This fungus is present in the mature ascomal stage on debris when it is removed from water. This indicates that it is actively reproducing in the aquatic environment.

\section{ACKNOWLEDGMENTS}

Appreciation is expressed to Dr. Donald P. Rogers for correcting the Latin diagnosis and to Dr. J. Leland Crane for collecting substrata. Financial support to the senior author from the National Science Foundation (Grant No. DEB-9200885 ) is gratefully acknowledged.

\section{LITERATURE CITED}

Barr, M. E. 1987. Prodromus to class Loculoascomycetes. Hamilton I. Newell, Inc., Amherst, Massachusetts, 168 pp.

Huhndorf, S. M. 1991. A method for sectioning ascomycete herbarium specimens for light microscopy. Mycologia 83: $520-524$.

Hyde, K. D. 1994. Aquatic fungi on rachides of Livistona in the Western Province of Papua New Guinea. Mycol. Res. 98: 719-725.

- 1995a. The genus Massarina, with a description of M. eburnea and an annotated list of Massarina names. Mycol. Res. 99: 291-296.

_. 1995b. Tropical Australian freshwater fungi. VII. New genera and species of Ascomycetes. Nova Hedwigia 61: 233-241.

—, and A. Aptroot. 1996. Fungi from palms. XXX. The genus Massarina, with two new species. Nova Hedwigia 62: (In press).

- , and B.D. Borse. 1986. Marine fungi from Seychelles. VI. Massarina velataspora, a new marine Ascomycotina from mangrove wood. Mycotaxon 27: 193212.

- L. L. P. Vrijmoed, S. Chinneraj, and E. B.G. Jones. 1992. Massarina armatispora sp. nov., a new intertidal ascomycete from mangroves. Bot. Mar. 35: 325-328.

Ingold, C. T. 1955. Aquatic ascomycetes: further species from the English Lake District. Trans. Brit. Mycol. Soc. 38: 157-168.

Kohlmeyer, J., and B. Volkmann-Kohlmeyer. 1987. Marine fungi from Aldabra, the Galapagos, and other tropical islands. Canad. J. Bot. 65: 571-582.

— 
to the filamentous higher marine fungi. Bot. Mar. 34: $1-61$.

Leuchtmann, A. 1984. Über Phaeosphaeria Miyake und andere bitunicate Ascomyceten mit mehrfach querseptierten Ascosporen. Sydowia 37: 79-195.

Magnes, M., and J. Hafellner. 1991. Ascomyceten auf Gefässpflanzen an Ufern von Gebirgsseen in den Ostalpen. Biblio. Mycol. 139: 1-182. J. Cramer, Stuttgart.

Munk, A. 1956. On Metasphaeria coccodes (Karst.) Sacc. and other fungi probably related to Massarina Sacc. (Massarinaceae n. fam.). Friesia 5: 303-308.

. 1957. Danish Pyrenomycetes. Dansk Bot. Ark. 17: $1-491$.
Scheuer, C. 1991. Massarina tetraploa sp. nov., the teleomorph of Tetraploa aristata. Mycol. Res. 95: 126-128.

Shearer, C. A. 1993. The freshwater Ascomycetes. Nova Hedwigia 56: 1-33.

Webster, J. 1965. The perfect state of Pyricularia aquatica. Trans. Brit. Mycol. Soc. 48: 449-452.

borne Hyphomycetes from fresh water. Pp. 419-451. In: The whole fungus. Vol. 2, Ed., W. B. Kendrick, National Museum of Natural Sciences, National Museums of Canada, Ottawa.

Willoughby, L. G., and J. F. Archer. 1973. The fungal spora of a freshwater stream and its colonization pattern on wood. Freshw. Biol. 3: 219-239. 